\title{
Investigating the combustion and emissions characteristics of biomass-derived platform fuels as gasoline extenders in a single cylinder spark-ignition engine
}

\author{
Midhat Talibi*, Paul Hellier, and Nicos Ladommatos \\ Department of Mechanical Engineering, University College London, Torrington Place, London WC1E 7JE, United Kingdom
}

\begin{abstract}
The conversion of lignocellulosic biomass to liquid fuels presents an alternative to the current production of renewable fuels for IC engines from food crops. However, realising the potential for reductions in net $\mathrm{CO}_{2}$ emissions through the utilisation of, for example, waste biomass for sustainable fuel production requires that energy and resource inputs into such processes be minimised. This work therefore investigates the combustion and emission characteristics of five intermediate platform molecules potentially derived from lignocellulosic biomass: gamma-valerolactone (GVL), methyl valerate, furfuryl alcohol, furfural and 2-methyltetrahydrofuran (MTHF).

The study was conducted on a naturally aspirated, water cooled, single cylinder spark-ignition engine. Each of the platform molecules were blended with reference fossil gasoline at $20 \% \mathrm{wt} / \mathrm{wt}$. The experiments were performed at constant engine speed (1200 rpm), with the throttle position and fuel flowrate being adjusted for every test to maintain a constant engine load and equivalence ratio (0.95-0.98). Knock limits were determined for each test fuel blend by advancing the spark timing, and heat release rates were analysed to investigate the impact of the platform molecules on flame propagation speeds. The lowest and highest knock limit were exhibited by furfural and furfuryl alcohol blends, respectively. Emissions of $\mathrm{NO}_{x}, \mathrm{CO}$, particulate mass and total particle number exhaust emissions showed a greater sensitivity to engine air fuel equivalence ratio than properties of the platform molecules tested as blends. The particulates from the furfural blend had peak particle diameters of $40 \mathrm{~nm}$, while those from furfural alcohol had a peak particle diameter of $80 \mathrm{~nm}$.
\end{abstract}

\section{Introduction}

While the vast majority of fuels for road transport continue to be produced from fossil oils, the need to reduce anthropogenic emissions of greenhouse gases, in particular carbon dioxide $\left(\mathrm{CO}_{2}\right)$, and attempt to limit the negative impacts of global climate change requires the development of sustainable renewable alternatives [1-3]. Concurrently there is a further need to limit the detrimental impacts of IC engines on local air quality and human health through the reduction of engine exhaust levels of toxic pollutants including nitrogen oxides (NOx) and particulate matter (PM) [4,5]. Legislative targets for the percentage of transportation fuels from renewable sources exist in the EU [6], US [7] and China [8], however, there is growing realization that the bio-fuels utilized in achieving these targets, primarily ethanol for spark ignition (SI) engines and biodiesel (fatty acid methyl esters) for diesel, compete with the cultivation of crops for food and may not be genuinely sustainable when considering the entirety of the fuel production lifecycle. The use of advanced biofuels and those from waste feedstocks which result in reduced negative environmental impact through indirect land use change (ILUC) are now being promoted, for example in the EU where the use of biofuels from food crops is restricted to $7 \%$ of the total fuel supply [9]. One potential feedstock for the sustainable production of liquid fuels is lignocellulosic biomass, often available as a waste material from the production of food crops $[10,11]$.

Furfural is an aromatic molecule obtainable via acid catalysed conversion of xylose [12] derived primarily from the hemicellulosic portion of ligno-cellulosic biomass [11]. Figure 1 shows in schematic form the side products formed during the hydrogenation of furfural to furfuryl alcohol and further molecules potentially produced by the further reactions of these products [12]. It can be seen in Figure 1 that through such reactions, in addition to a variety of $\mathrm{C} 5$ alcohols and ketones, a range of cyclic molecules with varying degrees of ring saturation and oxygen content can be obtained. For example, Kai Yan et al. [13] undertook the selective hydrogenation of furfural and levulinic acid and obtained 2-methylfuran and $\gamma$-valerolactone (GVL) at yields of 51\% and 90\% respectively.

Of the molecules potentially produced by hydrogenation of furfural derived from ligno-cellulosic biomass, 2-methyl furan (MF) has been amongst the most widely considered as a renewable fuel for spark ignition engines. As part of the Tailor-Made Fuels from Biomass Cluster of Excellence, Hoppe et al [14] investigated the ignition characteristics and exhaust emissions of 2-methyl furan relative to 2butanone, ethanol and a reference gasoline in a rapid compression machine (RCM) and highly boosted direct injection spark ignition engine respectively. While similar ignition times of 2-methyl furan relative to ethanol were observed in the RCM, in engine tests 2methyl furan exhibited greater knock resistance than conventional gasoline but less than that of ethanol due to a greater degree of incylinder charge evaporative cooling in the case of the latter. Engine exhaust emissions of particulates were observed to be lower in the case of the 2-methyl furan (and the other oxygenated molecules) relative to the fossil gasoline tested.

In a study of combustion characteristics and exhaust emissions of a direct injection spark ignition engine, Wang et al. [15] tested 2,5dimethylfuran, 2-methylfuran, ethanol and an unleaded fossil gasoline as single component fuels at a range of engine loads. While 2,5-

*corresponding author

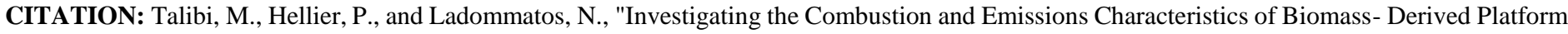

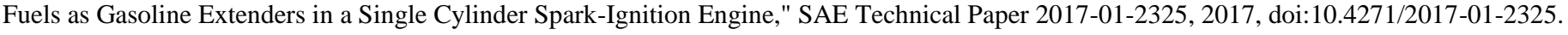


dimethylfuran exhibited similar burn rates and in-cylinder pressures as ethanol and the unleaded gasoline, 2-methylfuran displayed a significantly higher burn rate, generating higher in-cylinder pressures and reducing the incidence of knock. Lower exhaust emissions of unburnt hydrocarbons, formaldehyde and particulate matter but higher NOx levels were found in the combustion of 2-methyl furan relative to the other fuels tested, and were attributed to higher in-cylinder temperatures and an increased fuel oxygen content. Ma et al. [16], utilising laser induced fluorescence for measurement of $\mathrm{OH}$, also observed faster flame growth and flame speed in the case of 2methylfuran combustion relative to that of 2,5-dimethylfuran (which was exhibited flame characteristics similar to those of iso-octane). During tests in a PFI SI engine of 2-methylfuran as a $10 \%$ blend in a fossil gasoline, Wei et al. [17] observed this blend to have a shorter duration of combustion relative to pure gasoline and a $10 \%$ ethanol blend with gasoline. The 2-methylfuran blend was found to emit higher levels of NOx and reduced emissions of unburnt hydrocarbons and carbon monoxide, suggested to result from the higher combustion temperature of the furan. 2,5-dimethylfuran has also been considered as a fuel for compression ignition engines, with blends of $40 \%$ with fossil diesel found to dramatically reduce emissions of soot, with and without the addition of $2 \% 2$ EHN for the reduction of ignition delay times to those of the fossil diesel tested $[18,19]$.

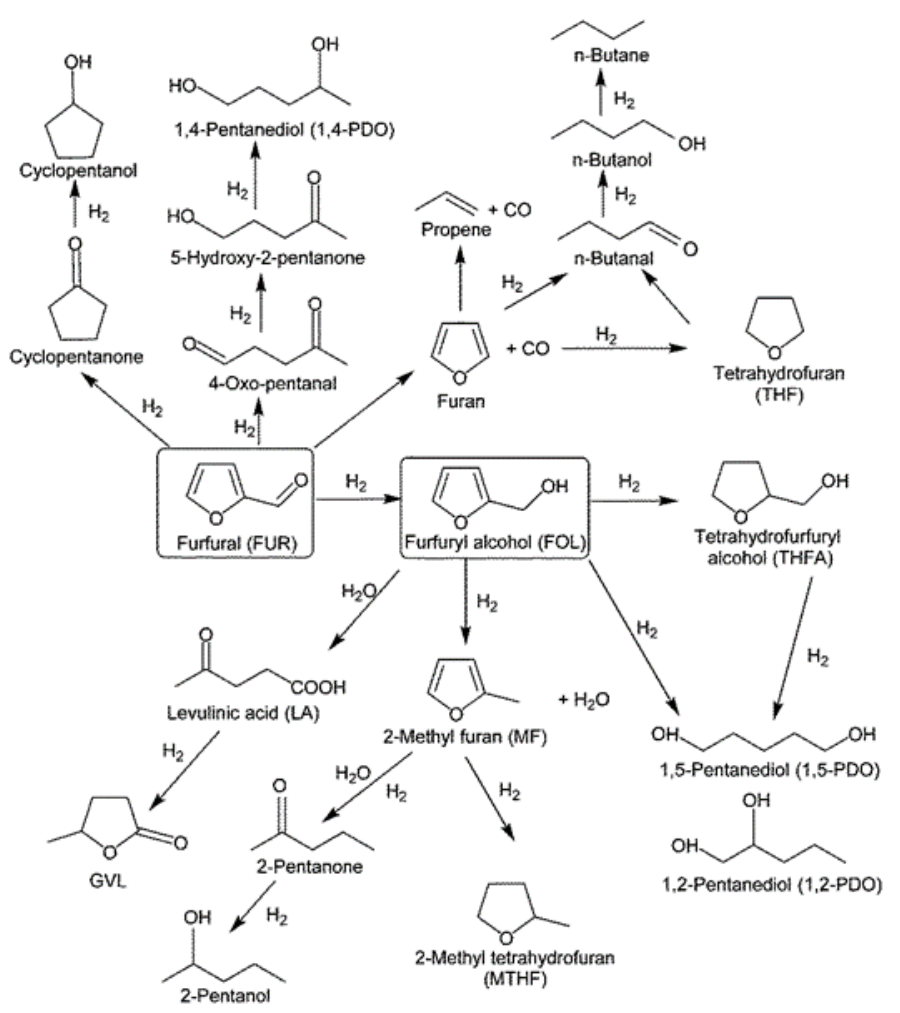

Figure 1: Potential products obtained by the hydrogenation of furfural (FUR) to furfuryl alcohol (FOL). Reproduced from Mariscal et al. [12] with permission from The Royal Society of Chemistry.

Wang et al. [20] undertook measurements of the ignition delay of 2-methylfuran and 2-methyltetrahydrofuran between $1050 \mathrm{~K}$ and 1800 $\mathrm{K}$ in a shock tube, and for a given condition consistently found longer ignition delay times for the more saturated furan (MTHF). Subsequent kinetic analysis of these shock tube measurements found the decomposition of MTHF relative to that of 2-methyl furan to result in lower concentrations of acytylene, and important precursor to the formation of polycyclic aromatic hydrocarbons and soot. In a literature assessment of potential oxygenated molecules for low temperature diesel homogenous charge compression ignition (HCCI), Janssen et al. [21] suggested that a blend of MTHF with di-n-butylether could result in near zero emissions of soot over a wide range of engine loads.

Sudholt et al. [22] utilised an ignition quality tester (IQT) to determine derived cetane numbers (DCN) of MTHF and furfural alcohol. The DCN of furfural alcohol was found to be significantly lower than that of MTHF (10.8 versus 20), while under the same conditions a fossil gasoline of RON 90 was found to have a DCN of 23, suggesting that both furans would exhibit a significant degree of knock resistance given the longer ignition delay times and thus lower rates of low temperature reactions exhibited by the IQT tests. Calculation of bond disassociates energies by Sudholt et al. [22] also found that the addition of a side chain to furans, such as in the case of furfural alcohol, to have a negligible effect on the overall reactivity of the molecules, whereas in the case of the more saturated tetrahydrofurans side chains were of far more importance in determining ignition quality. Considering the optimal molecular design of fuels for use as

CITATION: Talibi, M., Hellier, P., and Ladommatos, N., "Investigating the Combustion and Emissions Characteristics of Biomass- Derived Platform Fuels as Gasoline Extenders in a Single Cylinder Spark-Ignition Engine," SAE Technical Paper 2017-01-2325, 2017, doi:10.4271/2017-01-2325. 
octane boosters, Boot et al. [23], found the addition of ether or aldehyde oxygenated functional groups to be undesirable as they weaken adjacent $\mathrm{C}$ to $\mathrm{H}$ bonds, while the presence of an alcohol, ester or ketone group potentially enhances anti-knock characteristics as these functional groups can provide routes to decreasing the saturation of carbon to carbon bonds.

Valeric esters, including GVL (Figure 1), have also received some consideration as renewable fuel components for both SI and compression ignition engines. Lange et al. [24] determined blended research octane numbers of methyl valerate of approximately 120 , and for ethyl valerate of 100. Bereczky et al. [25] tested GVL as blends with fossil diesel and biodiesel fuels in a diesel engine, and observed higher NOx emissions. Koivisto et al. [26] tested a range of valerate esters in a modern direct injection diesel engine, including tests of ethyl, butyl and pentyl valerate tested as blends with $30 \% n$-heptane and found these molecules to have a significantly longer ignition delay than ketones or alkanes of equivalent carbon number.

This paper presents the results of SI engine tests of five molecules representing various stages of the processing of lignocellulosic biomass to liquid molecules via the production of furfural. For blends of gasoline and ethanol with each molecule the knock limit at wide open throttle was determined, while measurement of gaseous and particulate exhaust emission levels was undertaken at constant work out from the engine. These preliminary experiments therefore provide an indication of how the number of processing steps of biomass to fuels via furfural may be reduced while still providing a useful gasoline extender that contributes to energy release during combustion.

\section{Experimental Setup}

The current study was carried out on a naturally aspirated, single cylinder, poppet-valve, water-cooled, four-stroke, Ricardo E6 variable compression ratio engine. The compression ratio (CR) of the engine could be varied between 4.5 and 20, and for these set of experiments the $\mathrm{CR}$ was set to 10.3 . The relatively low $\mathrm{CR}$ and decision to operate the engine naturally aspirated was made as no prior engine tests of two of the molecules tested had been reported and so the severity of any potential knock that might be encountered in these tests could not be anticipated. Fuel and air (maintained at constant humidity for all experiments described in this paper) were mixed in a single barrel carburettor (Solex type 35 FA1), installed $150 \mathrm{~mm}$ upstream of the engine intake valves. The carburettor was fitted with a variable main jet, consisting of a tapered needle valve to allow control of the mixture strength being supplied to the combustion chamber. The fuel-air mixture was ignited in the combustion chamber with $14 \mathrm{~mm}$ spark plug (NGK BPR6HS), installed at the side of the combustion chamber between the valves. The timing of the spark was synchronised with the camshaft encoder and was controlled using an in-house developed NI LabVIEW program, via a very fast insulated gate bipolar transistor (IGBT - STGW20NC60VD), capable of operation up to $50 \mathrm{kHz}$. The in-cylinder gas pressure was measured, to a resolution of $0.4 \mathrm{CAD}$, using a water-cooled piezo-electric pressure transducer (Kistler 6041B), coupled to a Kistler 5007 charge amplifier. The in-cylinder pressure was pegged to intake manifold pressure at the piston BDC position every engine cycle - the intake pressure was measured using a piezo-resistive pressure transducer (Druck A5074, range 0-1 bar absolute) to an accuracy of $\pm 0.2 \%$ over the whole range. The in-cylinder pressure data was evaluated in real-time to determine net apparent heat release rates and derive indicated mean effective pressures (IMEP). The in-cylinder pressure trace was also processed in real-time to determine the frequency of combustion cycles that knocked. This was done by feeding the incylinder pressure trace through a band-pass filter to single out the characteristic knock frequencies, and if the amplitude of the filtered trace went above a pre-determined threshold, the cycle was counted as knock combustion [27]. Various temperatures including engine exhaust and intake manifold were measured with k-type thermocouples. All the pressures, temperatures and other operational parameters were monitored live and logged on PCs using NI data acquisition systems. The geometry specifications of the engine assembly, and other particulars of the test setup have been listed in Table 1, while Figure 2 shows a schematic of the test facility.

Table 1. Ricardo E6 engine Specifications

\begin{tabular}{|l|l|}
\hline Number of cylinders & 1 \\
\hline Valves & 1 inlet, 1 exhaust \\
\hline Bore & $76.2 \mathrm{~mm}$ \\
\hline Stroke & $111.13 \mathrm{~mm}$ \\
\hline Swept volume & $506.8 \mathrm{~cm}^{3}$ \\
\hline Oil temperature & $60 \pm 2.5^{\circ} \mathrm{C}$ \\
\hline Coolant temperature & $60 \pm 2.5^{\circ} \mathrm{C}$ \\
\hline Compression ratio (geometric) & $10.3: 1$ \\
\hline Carburettor & Solex type 35 FA1 \\
\hline Spark plug & NGK BPR6HS $14 \mathrm{~mm}$ \\
\hline
\end{tabular}

CITATION: Talibi, M., Hellier, P., and Ladommatos, N., "Investigating the Combustion and Emissions Characteristics of Biomass- Derived Platform Fuels as Gasoline Extenders in a Single Cylinder Spark-Ignition Engine," SAE Technical Paper 2017-01-2325, 2017, doi:10.4271/2017-01-2325. 


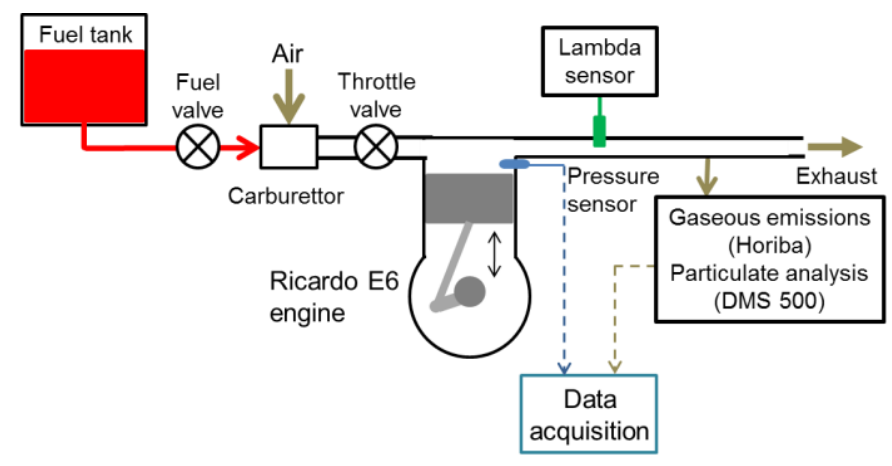

Figure 2: Schematic showing Ricardo E6 test engine facility

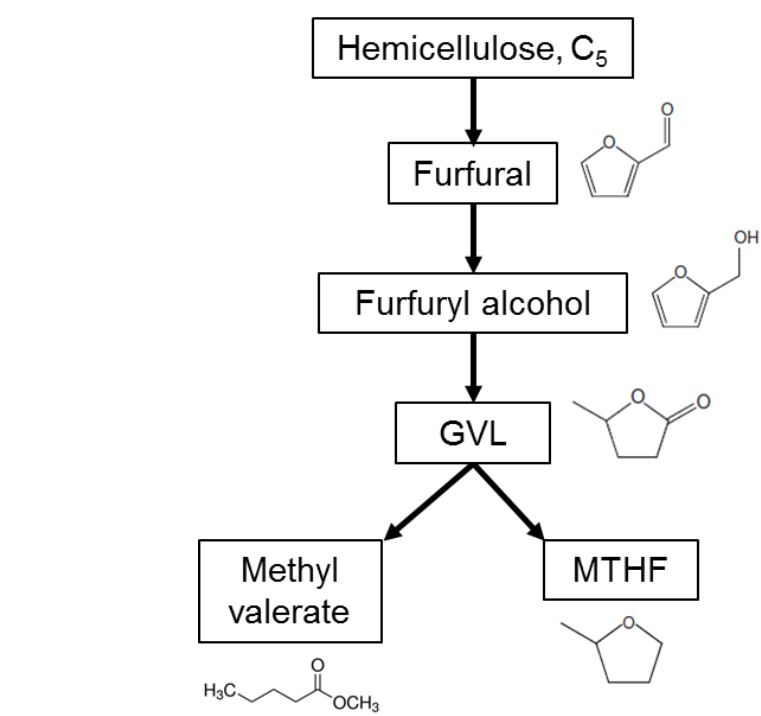

Figure 3: Pathway of hemicellulose conversion, and the structure of molecules tested in this study.

$\mathrm{An}_{2}$ /lambda sensor (ECM AFRecorder 1200), mounted $120 \mathrm{~mm}$ away from the engine exhaust valve, was used to determine the incylinder mixture stoichiometry. The $\mathrm{O}_{2}$ sensor could be calibrated for different fuel blends by loading the hydrogen-to-carbon (H:C) and oxygen-to-carbon $(\mathrm{O}: \mathrm{C})$ mass ratios for each fuel blend into the control unit of the sensor, which then computed the calibration curves accordingly. Exhaust emissions were sampled $200 \mathrm{~mm}$ downstream of the of engine exhaust valve and fed via heated lines to a Horiba MEXA-9100EGR automotive gas analyser rack for measuring gaseous emissions, and to a Cambustion DMS500 differential mobility spectrometer to determine the number and size distribution of particulates in the exhaust. The Horiba analyser rack was fitted with a non-dispersive infrared absorption analyser for $\mathrm{CO}( \pm 1 \mathrm{ppm})$ and $\mathrm{CO}_{2}( \pm 0.01 \%)$ measurement, a flame ionization detector for THC ( $\pm 10 \mathrm{ppm})$ measurement (though it should be noted that no compensation was made the for presence of ethanol in the tested fuels; previous studies have shown that misinterpretation of FID measured THC levels can occur in fuels containing alcohols [28]), a magnetopneumatic analyser for oxygen $( \pm 0.1 \%)$ measurement, and a chemiluminescence analyser to measure $\mathrm{NO}_{\mathrm{x}}( \pm 1 \mathrm{ppm})$ concentrations in the exhaust gas. An IKA C1 bomb calorimeter was used to measure the higher heating values of the test fuels, from which the lower heating value for each was calculated.

\section{Experimental Methodology}

\section{Fuels investigated}

Five fuel molecules, furfural, furfuryl alcohol, gamma-valerolactone (GVL), 2-methyltetrahydrofuran (MTHF) and methyl valerate, were selected for this work. These molecules occur as stable intermediate liquid molecules in the conversion process of lignocellulosic biomass to long chain alkanes, and are potential platform molecules to be used as fuels, fuel additives or chemical solvents [29-31]. Figure 3 shows a simplified pathway of the conversion of hemicellulose $\left(\mathrm{C}_{5}\right.$ sugars) to these platform molecules (and their molecular structures), with each additional step of processing requiring a further input of energy and reactants. Each of these five molecules were mixed with reference fossil gasoline ( $\mathrm{C}: \mathrm{H}$ mass ratio $-6.84, \mathrm{O}_{2}$ content $<0.87 \%$ by mass) in a $20 \%$ by mass ratio (to allow for accurate calculation of fuel blend elemental ratios), but as some of these molecules were found to be immiscible with gasoline, $5 \%$ ethanol (wt/wt) was added to each blend. For reference, pure fossil gasoline, and a binary blend of 5\% ethanol/95\% gasoline (wt/wt) was also tested at the different operating conditions. Table 2 shows the physical and chemical properties of the test fuels and reference gasoline (including the lower heating values of the individual test fuels), while Table 3 summarises the operating conditions of the test fuel blend engine experiments.

CITATION: Talibi, M., Hellier, P., and Ladommatos, N., "Investigating the Combustion and Emissions Characteristics of Biomass- Derived Platform Fuels as Gasoline Extenders in a Single Cylinder Spark-Ignition Engine," SAE Technical Paper 2017-01-2325, 2017, doi:10.4271/2017-01-2325. 
Table 2: Fuel properties (a) - From supplier certificates/specification sheets, (b) - From European Chemicals Agency (ECHA) datasheets, * tested at $15{ }^{\circ} \mathrm{C}$.

\begin{tabular}{|c|c|c|c|c|c|c|c|}
\hline & $\begin{array}{c}\text { Molecular } \\
\text { formula }\end{array}$ & $\operatorname{Assay}(\%)^{a}$ & $\mathbf{T}_{\mathbf{b} . \mathbf{p}}\left({ }^{\circ} \mathbf{C}\right)^{\mathbf{a}}$ & $\begin{array}{c}\text { Density @ } 20^{\circ} \mathrm{C} \\
\left(\mathrm{kg} / \mathrm{m}^{3}\right)^{\mathrm{a}}\end{array}$ & $\begin{array}{c}\text { Dynamic viscosity } \\
@ 25^{\circ} \mathrm{C}(\mathrm{mPa} . \mathrm{s})^{\mathrm{b}}\end{array}$ & $\begin{array}{c}\text { LHV } \\
(\mathrm{MJ} / \mathrm{kg})\end{array}$ & $\mathbf{R O N}[32]$ \\
\hline Furfural & $\mathrm{C}_{5} \mathrm{H}_{4} \mathrm{O}_{2}$ & 99 & 162 & 1160 & 1.49 & 23.21 & - \\
\hline Furfuryl alcohol & $\mathrm{C}_{5} \mathrm{H}_{6} \mathrm{O}_{2}$ & 98 & 170 & 1135 & 4.62 & 24.51 & - \\
\hline GVL & $\mathrm{C}_{5} \mathrm{H}_{8} \mathrm{O}_{2}$ & $\geq 99$ & 208 & 1050 & 2.18 & 24.53 & 100 \\
\hline MTHF & $\mathrm{C}_{5} \mathrm{H}_{10} \mathrm{O}$ & $\geq 99$ & 80 & 860 & 4 & 33.68 & 86 \\
\hline Methyl valerate & $\mathrm{C}_{6} \mathrm{H}_{12} \mathrm{O}_{2}$ & $\geq 99$ & 128 & 875 & - & 27.82 & 105 \\
\hline Ethanol & $\mathrm{C}_{2} \mathrm{H}_{6} \mathrm{O}$ & $\geq 99$ & 78 & 790 & 1.10 & 27.05 & 109 \\
\hline $\begin{array}{c}\text { Reference fossil } \\
\text { gasoline }\end{array}$ & - & - & 201.2 & $749.8^{*}$ & - & $42.75^{\mathrm{a}}$ & $95.6^{\mathrm{a}}$ \\
\hline
\end{tabular}

Table 3: Engine experiment operating conditions

\begin{tabular}{|c|c|c|c|c|c|c|c|c|c|c|}
\hline \multirow[b]{2}{*}{$\begin{array}{c}\text { Fuel } \\
\text { blend } \\
\text { (wt/wt) }\end{array}$} & \multirow[b]{2}{*}{$\begin{array}{c}\text { In-text } \\
\text { reference }\end{array}$} & \multirow{2}{*}{$\begin{array}{c}\text { Lower } \\
\text { heating } \\
\text { value } \\
\text { (MJ/Kg) }\end{array}$} & \multicolumn{4}{|c|}{ Knock limit detection } & \multicolumn{4}{|c|}{ Constant spark timing } \\
\hline & & & $\begin{array}{c}\text { Spark } \\
\text { timing } \\
\text { (CAD } \\
\text { BTDC) }\end{array}$ & Lambda & $\begin{array}{c}\text { Intake } \\
\text { temperature } \\
{ }^{\circ} \mathrm{C}\end{array}$ & $\begin{array}{c}\text { Exhaust } \\
\text { temperature } \\
{ }^{\circ} \mathrm{C}\end{array}$ & $\begin{array}{c}\text { Spark } \\
\text { timing } \\
\text { (CAD } \\
\text { BTDC) }\end{array}$ & Lambda & $\begin{array}{c}\text { Intake } \\
\text { temperature } \\
{ }^{\circ} \mathrm{C}\end{array}$ & $\begin{array}{c}\text { Exhaust } \\
\text { temperature } \\
{ }^{\circ} \mathrm{C}\end{array}$ \\
\hline $\begin{array}{c}\text { Pure } \\
\text { gasoline }\end{array}$ & 100GSL & 42.75 & 16.0 & 0.976 & 22.60 & 475.98 & 10 & 0.979 & 22.32 & 475.98 \\
\hline $\begin{array}{c}5 \% \\
\text { ethanol + } \\
95 \% \\
\text { gasoline }\end{array}$ & $\begin{array}{l}\text { 5ETH- } \\
\text { 95GSL }\end{array}$ & 41.96 & 18.5 & 0.980 & 24.76 & 394.84 & 10 & 0.982 & 24.82 & 486.78 \\
\hline $\begin{array}{c}20 \% \\
\text { furfural + } \\
5 \% \\
\text { ethanol + } \\
75 \%\end{array}$ & $\begin{array}{l}\text { 20FUR- } \\
5 \mathrm{ETH}- \\
75 \mathrm{GSL}\end{array}$ & 38.06 & 15.5 & 0.984 & 22.86 & 454.94 & 10 & 0.973 & 24.77 & 467.10 \\
\hline $\begin{array}{c}20 \% \\
\text { furfuryl } \\
\text { alcohol + } \\
5 \% \\
\text { ethanol + } \\
75 \% \\
\text { gasoline }\end{array}$ & $\begin{array}{l}\text { 20FurAl- } \\
\text { 5ETH- } \\
\text { 75GSL }\end{array}$ & 38.32 & 23.5 & 0.976 & 24.67 & 434.82 & 10 & 0.950 & 22.31 & 462.15 \\
\hline $\begin{array}{c}20 \% \\
\text { GVL + } \\
5 \% \\
\text { ethanol + } \\
75 \% \\
\text { gasoline }\end{array}$ & $\begin{array}{l}20 \mathrm{GVL}- \\
5 \mathrm{ETH}- \\
75 \mathrm{GSL}\end{array}$ & 38.32 & 22.0 & 0.990 & 24.42 & 452.68 & 10 & 0.979 & 23.99 & 468.25 \\
\hline $\begin{array}{c}20 \% \\
\text { MTHF + } \\
5 \% \\
\text { ethanol + } \\
75 \% \\
\text { gasoline }\end{array}$ & $\begin{array}{l}\text { 20MTHF- } \\
\text { 5ETH- } \\
\text { 75GSL }\end{array}$ & 40.15 & 15.5 & 0.952 & 24.43 & 444.05 & 10 & 0.971 & 24.46 & 449.00 \\
\hline $\begin{array}{c}20 \% \\
\text { methyl } \\
\text { valerate } \\
+5 \% \\
\text { ethanol + } \\
75 \% \\
\text { gasoline }\end{array}$ & $\begin{array}{l}\text { 20MeVal- } \\
\text { 5ETH- } \\
75 \mathrm{GSL}\end{array}$ & 38.98 & 20.0 & 0.977 & 24.34 & 451.00 & 10 & 0.972 & 24.69 & 465.94 \\
\hline
\end{tabular}

CITATION: Talibi, M., Hellier, P., and Ladommatos, N., "Investigating the Combustion and Emissions Characteristics of Biomass- Derived Platform Fuels as Gasoline Extenders in a Single Cylinder Spark-Ignition Engine," SAE Technical Paper 2017-01-2325, 2017, doi:10.4271/2017-01-2325. 


\section{Test procedure}

For all experiments, the engine was operated at a constant speed of $1200 \mathrm{rpm}$; this relatively low engine speed was selected due to the limited availability of some test fuels. Initial tests of the fuel blends were carried out to determine the knock limit of each. For these tests, the engine was run with a wide-open throttle (WOT) to maintain a constant effective compression ratio and promote knock. The $\mathrm{O}_{2} /$ lambda sensor was constantly monitored and the carburettor fuel flow valve varied so as to maintain for most fuels a constant $\lambda=$ $0.98 \pm 0.01$, with the cycle-to-cycle variability encountered during engine knock resulting in the largest fluctuations in the air fuel stoichiometry (Table 3). The spark timing was then advanced in intervals of $0.5 \mathrm{CAD}$, and the knocking frequency (that is, the number of cycles that undergo knock over a 10 engine cycle period) monitored. The threshold for a cycle to be considered having undergone knock combustion was set to 1 bar (as below this knocking was considered to be indistinguishable from pressure trace measurement noise), and the knock limit for a particular fuel blend was determined to have been reached if the knocking frequency went above $50 \%$.

A second set of engine tests was conducted to determine the combustion and exhaust emissions characteristics of each test fuel blend with heat release occurring as close to TDC as possible without encountering engine knock. The spark timing was fixed at 10 CAD BTDC so that at all fuels tested experienced similar in-cylinder pressure and temperature conditions at the time of ignition, and the engine load was maintained at 9 bar IMEP to reflect in-vehicle engine operation where a specific engine work out is required regardless of fuel properties. The engine load was kept constant by varying the position of the throttle valve for the different fuel blends, while also changing the fuel flow to the carburettor to keep the lambda value constant at $\lambda=0.977 \pm 0.005$ (excluding furfuryl alcohol, emissions for which are reported at $\lambda=0.95$ due to limited fuel availability). The relevant engine pressures and exhaust emissions data was then logged for the fuel blends and reference gasoline.

\section{Results and Discussion}

\section{Knock limits}

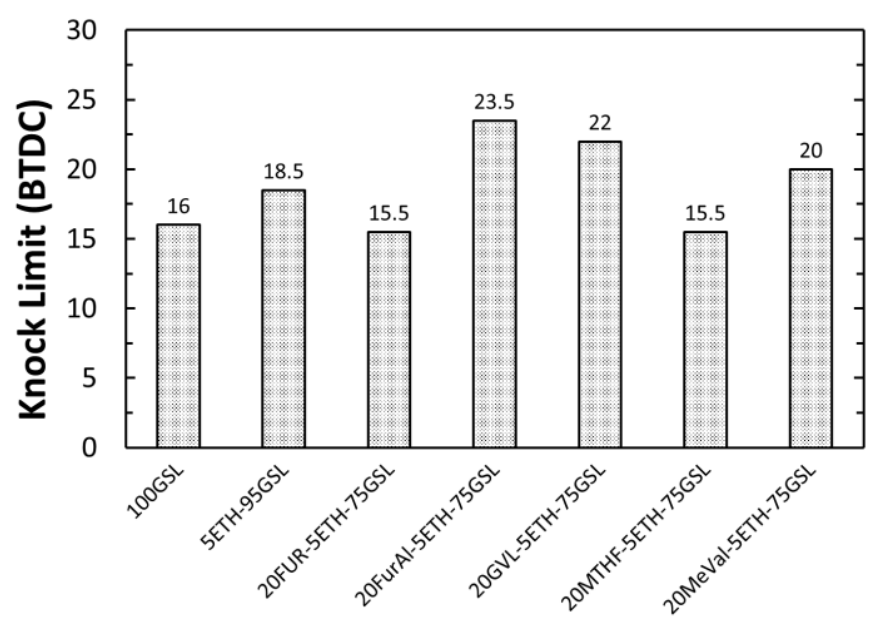

Figure 3: Knock limits for the various fuel blends, with wide open throttle (WOT) and lambda $=1$.

Figure 3 shows the knock limits for the various fuel blends, and for the reference fuel gasoline and the gasoline-ethanol blend. These tests were conducted with the engine running with at WOT, and spark timing was advanced until the knocking frequency reached a predetermined limit. For convenience, the knock limits of the all the fuel blends tested has been listed below in increasing order of knock resistance.

- Furfural and MTHF

- Gasoline

- Gasoline-ethanol

- Methyl valerate

- GVL

- Furfuryl alcohol

CITATION: Talibi, M., Hellier, P., and Ladommatos, N., "Investigating the Combustion and Emissions Characteristics of Biomass- Derived Platform Fuels as Gasoline Extenders in a Single Cylinder Spark-Ignition Engine," SAE Technical Paper 2017-01-2325, 2017, doi:10.4271/2017-01-2325. 
As can be observed from Table 3, MTHF has a considerably lower octane rating of 86 as compared to the reference gasoline (RON 96.5), and the other fuel molecules tested (Note: octane ratings for furfural and furfuryl alcohol were not available from literature), and therefore it could be expected that blending 20\% MTHF with gasoline would lower the overall knock resistance of the blend. The lower knock resistance of MTHF relative to furfuryl alcohol is in agreement with the IQT tests of Sudholt et al. [22] and the conclusions of Boot et al. [23], which highlight the importance of both unsaturated molecules and oxygenated sides chains in facilitating the production of stable intermediates during low temperature reactions. It should be noted that all the blends contain 5\% ethanol, and since ethanol has a significantly higher octane rating of 109 (Table 2), the effect of adding a lower RON fuel such as MTHF is countered to some extent by the ethanol. For fuel molecules, such as methyl valerate and GVL, which have higher octane ratings relative to the reference gasoline (Table 2), it is expected that their blends would be more resistant to knock. Considering the molecules with the two extreme knock limits - furfural and furfuryl alcohol - it is interesting to note that the only difference in their molecular structure is that the furfural has an aldehyde (-CHO) branch, while the furfuryl alcohol has a hydroxy (-OH) branch. The $\mathrm{OH}$ functional group in the furfuryl alcohol significantly increases the knock resistance of the fuel molecule. This is because the $\mathrm{OH}$ has a very strong bond dissociation energy, making it difficult to abstract the hydrogen atom - which is usually one of the initiating steps in the low temperature reactions which result in fuel ignition. The presence of the hydroxy moiety weakens the $\mathrm{C}$-H bond at the adjacent carbon ( $\alpha$-site), making it easier for these hydrogen atoms to be abstracted $[33,34]$. This could lead to the formation of thermally stable radicals, and thus, greatly reduce the low temperature reactivity of furfuryl alcohol relative to furfural $[23,35,36]$.

\section{Combustion characteristics}
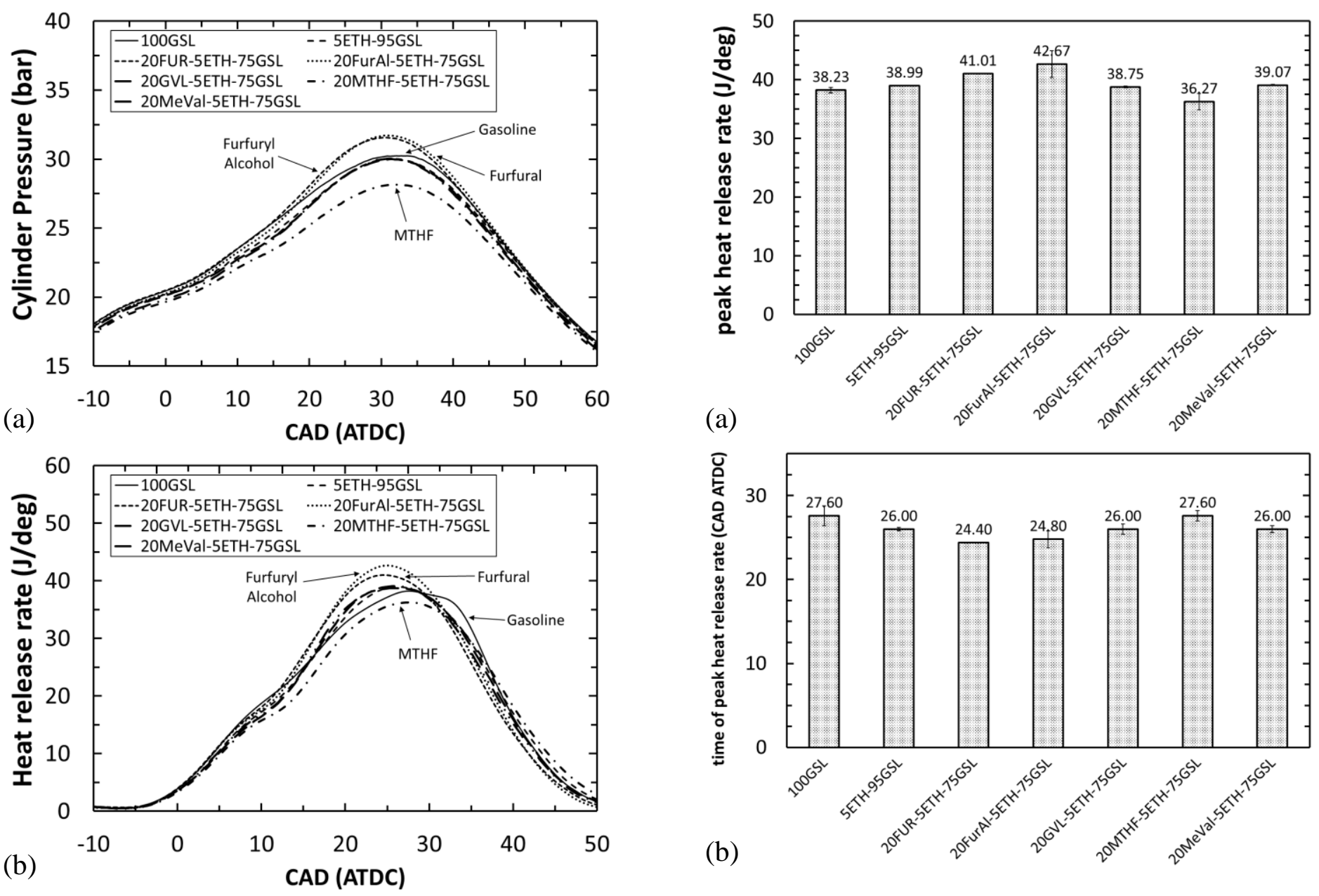

Figure 4: In-cylinder pressure traces and apparent net heat release rate curves for the various fuel blends, at a constant spark timing of 10 CAD BTDC and engine load of 9 bar IMEP.

Figure 5: (a) peak heat release rates and (b) time of peak heat release rates for the various fuel blends, at a constant spark timing of $10 \mathrm{CAD}$ BTDC and engine load 9 bar IMEP.

Figure 4 shows the in-cylinder gas pressure and net apparent heat release rate curves for the different fuel blends, at a fixed spark timing of 10 CAD BTDC and a constant engine load of 9 bar IMEP. The in-cylinder pressure curves shown in the figure have been averaged

CITATION: Talibi, M., Hellier, P., and Ladommatos, N., "Investigating the Combustion and Emissions Characteristics of Biomass- Derived Platform Fuels as Gasoline Extenders in a Single Cylinder Spark-Ignition Engine," SAE Technical Paper 2017-01-2325, 2017, doi:10.4271/2017-01-2325. 
over a period of 200 consecutive engine cycles. The net heat release rates were evaluated from the in-cylinder pressure data, utilizing a one dimensional and single zone thermodynamic model and assuming homogenous conditions and ideal gas behaviour [37]. Given the fixed spark timing, it can be suggested that differences visible in both in-cylinder pressure and heat release rates can be attributed to differences in the physical and chemical properties of the test fuel blends. From the heat release rate curves (Figure 4b), it can be observed that following the ignition event, the increase in heat release rate is quite similar for the different fuel blends, up to $10 \mathrm{CAD}$ ATDC. Beyond 10 CAD ATDC, the rate of increase of heat release is highest for the furfural blend and the furfuryl alcohol blend, and the lowest for the MTHF blend.

Figure 5 shows the peak heat release rates (pHRR) and the time (in CAD) at which the peak heat release rate occurs (tPHRR) for the various fuel blends, at a fixed spark timing of 10 CAD BTDC and a constant engine load of 9 bar IMEP. Where shown in Figure 5 and subsequent plots, the error bars included display the mean measurement point plus and minus the range of measurements made over the course of 200 engine cycles. The highest pHRR is exhibited by the furfuryl alcohol (FurAl) blend of $42.67 \mathrm{~J} / \mathrm{deg}$, while the lowest pHRR of $36.27 \mathrm{~J} / \mathrm{deg}$ by the MTHF blend. In addition, for the furfuryl alcohol blend, the pHRR occurs relatively early in the expansion stroke at 24.80 CAD ATDC, as compared to the MTHF blend which occurs at 27.60 CAD ATDC, implying faster burn rates in the case of the furfuryl alcohol blend. The difference in the rate of increase of heat release between the furfuryl alcohol blend and MTHF blend (Figure $4 \mathrm{~b}$ ), can potentially be attributed to their respective molecular structures. The MTHF molecule, upon undergoing $\mathrm{H}$ abstraction from the methyl group (which is typically one of the first reactions in the low temperature fuel breakdown pathway), could potentially result in the formation of radicals which are thermally more stable as compared to the radicals formed during breakdown of the furfuryl alcohol molecule [12,23], resulting in longer ignition delays at high temperatures, and thus slower flame propagation speeds, relative to less saturated furans [20]. Furthermore, given that pHRR occurs in the expansion stroke for both blends (Figure 5b), an earlier occurrence of the pHRR (as in the case of the furfuryl alcohol blend) implies that the energy is being released in an environment of comparatively higher in-cylinder pressures and temperatures. Additionally, as the expansion stroke progresses, thermal energy losses to the cylinder walls increase as a larger surface area is available for heat transfer. Therefore, as a result of both these factors, pHRR tend to be higher if the bulk of the heat release occurs closer to the TDC position.

Figure 6 shows the indicated thermal efficiency and the combustion efficiency (as calculated in accordance to the method described by Heywood [37]) for the test fuel blends tested at a constant spark timing of 10 CAD BTDC and an engine load of 9 bar IMEP. It can be seen in Figure 6a that the highest and lowest thermal efficiencies of $30.22 \%$ and $28.84 \%$ were observed in the case of the furfural and methyl valerate blends respectively. Figure $6 \mathrm{~b}$ shows the lowest combustion efficiency of $38.55 \%$ displayed by the furfuryl alcohol blend; this can be attributed to the richer air fuel; mixture during the test of the furfuryl alcohol relative to the other test fuels and reference gasoline (Table 3). Notwithstanding the rich operation of the test engine during the fuel blend experiments (and thus low combustion efficiencies of less than $60 \%$ ), it is interesting to note that both the indicated thermal efficiency and combustion efficiency of engine was not significantly affected by the substitution of $20 \%$ of the fuel mass with the test fuels.
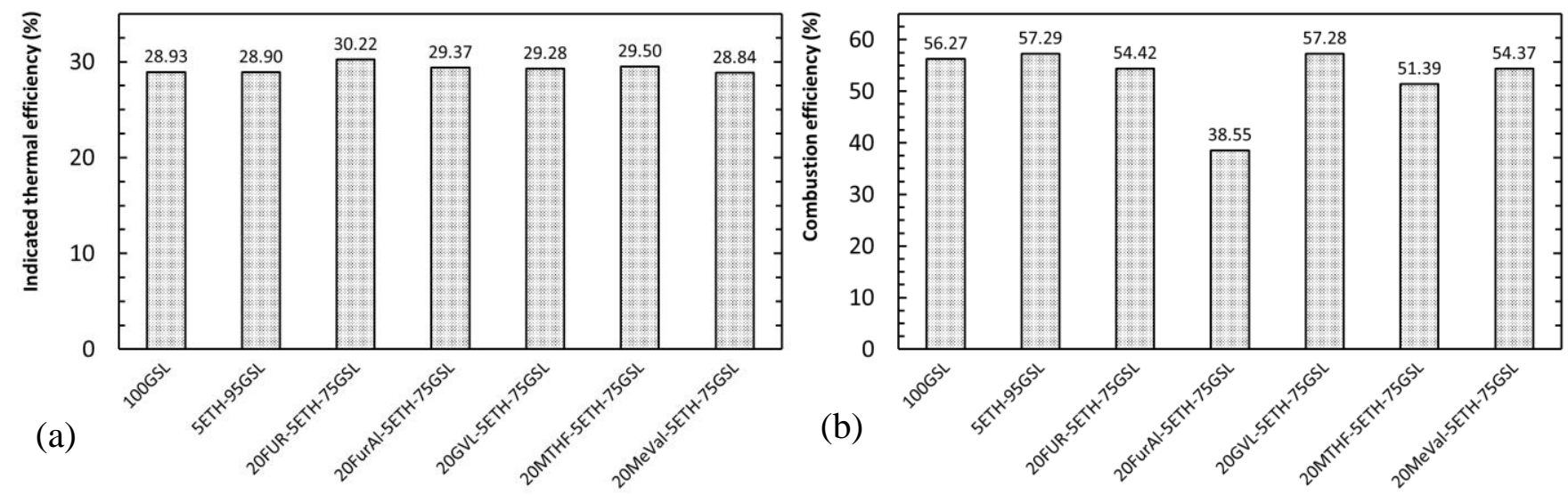

Figure 6: (a) indicated thermal efficiency (\%) and (b) combustion efficiency (\%) for the various fuel blends, at a constant spark timing of 10 CAD BTDC and engine load 9 bar IMEP.

CITATION: Talibi, M., Hellier, P., and Ladommatos, N., "Investigating the Combustion and Emissions Characteristics of Biomass- Derived Platform Fuels as Gasoline Extenders in a Single Cylinder Spark-Ignition Engine," SAE Technical Paper 2017-01-2325, 2017, doi:10.4271/2017-01-2325. 

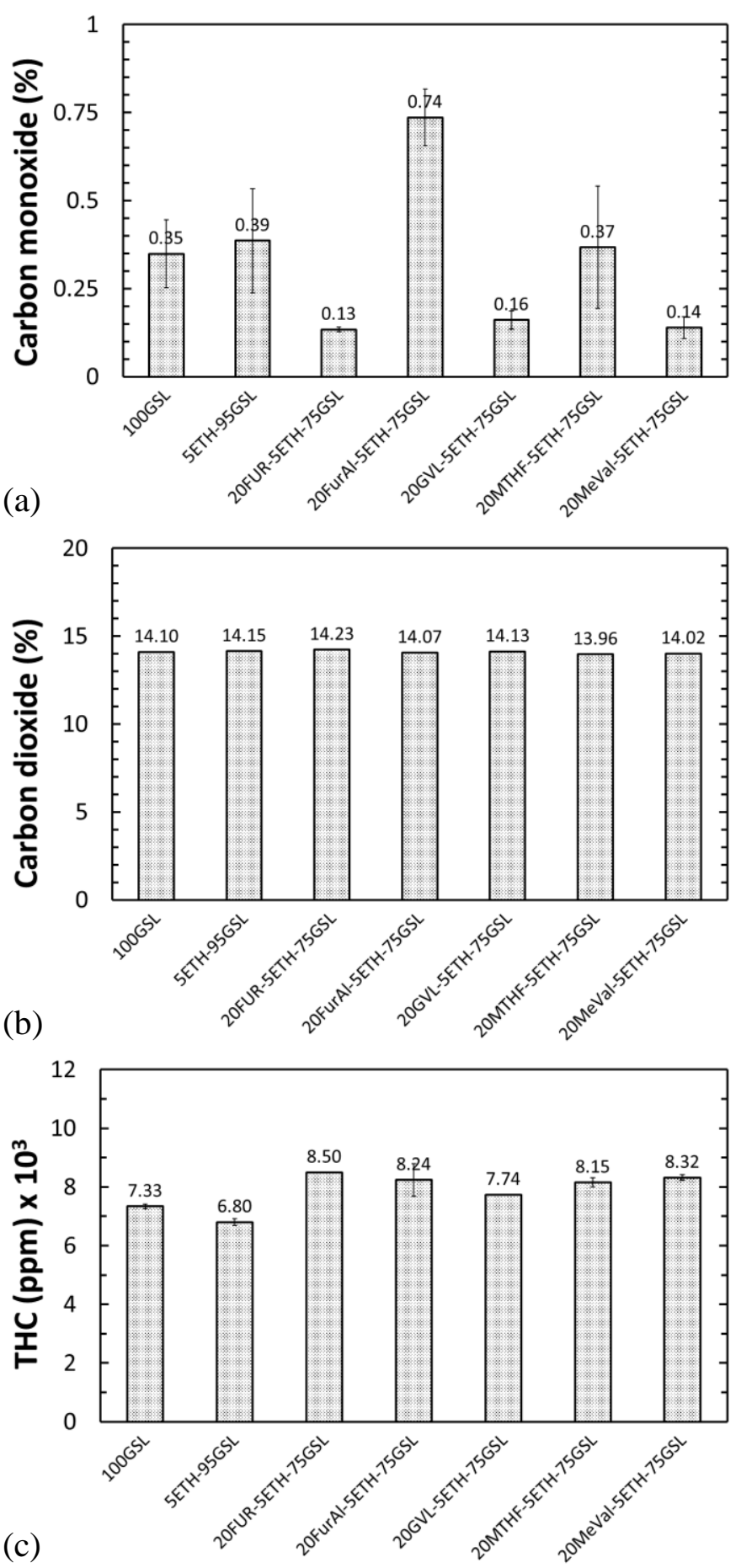

Figure 7: Exhaust emissions of (a) $\mathrm{CO}$, (b) $\mathrm{CO}_{2}$ and (c) unburned total hydrocarbons (THC) for the various fuel blends, at a constant spark timing of 10 CAD BTDC and engine load 9 bar IMEP.

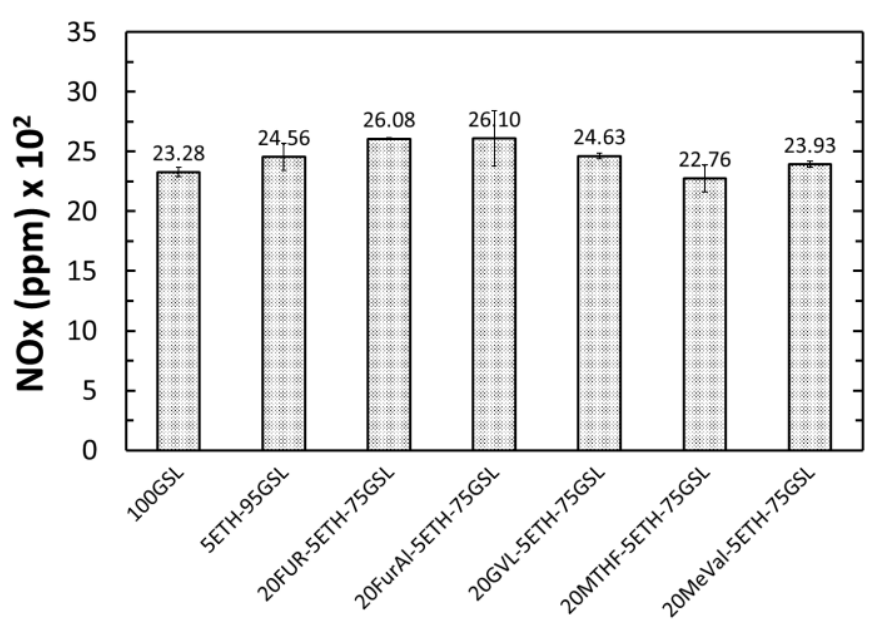

Figure 8: Exhaust emissions of NOx for the various fuel blends, at a constant spark timing of 10 CAD BTDC and engine load 9 bar IMEP.
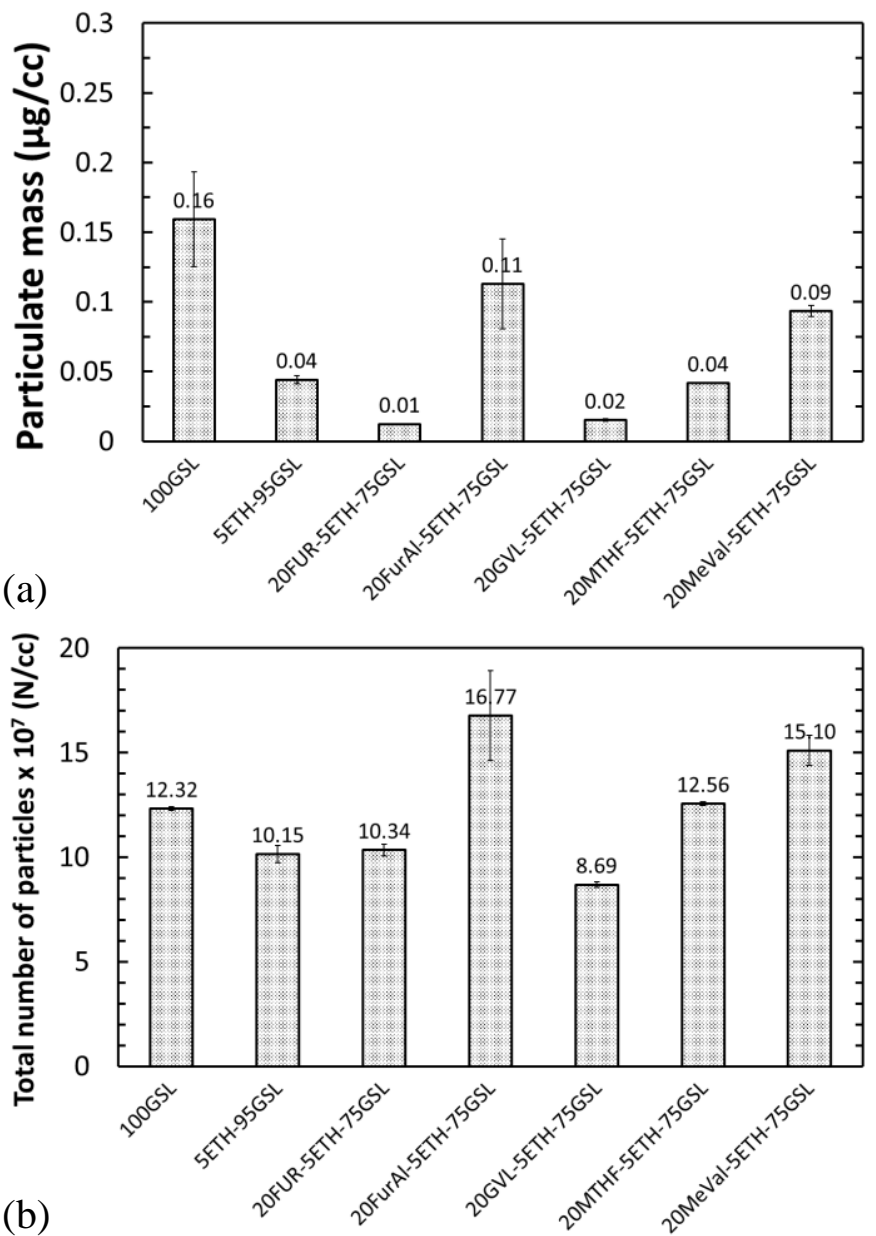

Figure 9: Exhaust emissions of (a) particulate mass and (b) total number of particles for the various fuel blends, at a constant spark timing of $10 \mathrm{CAD}$ BTDC and engine load 9 bar IMEP.

CITATION: Talibi, M., Hellier, P., and Ladommatos, N., "Investigating the Combustion and Emissions Characteristics of Biomass- Derived Platform Fuels as Gasoline Extenders in a Single Cylinder Spark-Ignition Engine," SAE Technical Paper 2017-01-2325, 2017, doi:10.4271/2017-01-2325. 
Figure 7 shows the exhaust gas emissions of $\mathrm{CO}, \mathrm{CO}_{2}$ and unburned hydrocarbons (THC) from the combustion of the test fuel blends at a fixed spark timing of 10 CAD BTDC and a constant engine load of 9 bar IMEP. First considering the exhaust CO emissions (Figure $7 \mathrm{a}$ ), it can be observed that the furfuryl alcohol (FurAl) blend produced a significantly higher amount of CO emissions as compared to any of the other fuel blends, which can likely be attributed to the richer air fuel mixture in the case of the furfuryl alcohol engine test (Table 3) resulting in insufficient levels of oxygen for complete combustion. This was followed by the MTHF blend which produced considerable $\mathrm{CO}$ emissions relative to the other fuel blends, although the $\mathrm{CO}$ emissions were similar to the reference gasoline and the gasoline-ethanol blend. The higher CO emissions of the furfuryl alcohol blend and of the MTHF blend may also be attributable to the considerably higher viscosity of both molecules (furfuryl alcohol - $4.62 \mathrm{mPa} . \mathrm{s}$, MTHF $4 \mathrm{mPa} . \mathrm{s}$ ), relative to the other fuel molecules tested (Table 2). The higher viscosity of the two fuels reduces the efficiency of fuel air mixing and thus rates of complete oxidation resulting in the formation of partially oxidised products such as $\mathrm{CO}$. Now considering the exhaust $\mathrm{CO}_{2}$ emissions, it can be observed in Figure $7 \mathrm{~b}$ that the $\mathrm{CO}_{2}$ emissions were very similar for all the fuel blends tested, and also the reference gasoline and the gasoline-ethanol blend. This could possibly be because the carbon-to-hydrogen $(\mathrm{C}: \mathrm{H})$ ratios of the fuel blends tested are not too dissimilar from each other, hence resulting in comparable $\mathrm{CO}_{2}$ emissions for constant engine work out. Figure 7c shows all of the test fuel blends to have emitted higher levels of THC than both the reference gasoline and ethanol gasoline blend, while the relatively high levels of THC for all fuels can be attributed to the rich operation of the engine (Table 3).

Figure 8 shows the exhaust gas emissions of $\mathrm{NO}_{\mathrm{x}}$ from the various fuel blends tested in this study, at a fixed spark timing of $10 \mathrm{CAD}$ BTDC and a constant engine load of 9 bar IMEP. Of all the fuel blends tested, the highest $\mathrm{NO}_{\mathrm{x}}$ emissions were exhibited by the furfuryl alcohol blend, while the lowest $\mathrm{NO}_{\mathrm{x}}$ emissions were from the MTHF blend, a trend which is concurrent with the peak heat release rates (Figure 5a). This is to be expected as peak heat release rates are indicative of the in-cylinder temperatures. As demonstrated in the extended Zeldovich mechanism, determined by Bowman and Miller [38-40], NOx formation rates are highly thermally sensitive and increase significantly under conditions of higher temperatures.

Figure 9 shows the total exhaust particulate mass and the number of particles in the engine exhaust from the various fuel blends tested in this study, at a fixed spark timing of 10 CAD BTDC and a constant engine load of 9 bar IMEP. It can be seen in Figure 9a that all of the test fuel blends emitted lower levels of particulate matter than the reference fossil gasoline, and it is tentatively suggested that this is attributable to the presence of oxygen within the test fuel molecules (Figure 3) [14,41]. Of the test fuel blends, it can be seen that the highest particulate mass was emitted by furfuryl alcohol (Figure 9a), in agreement with the lowest combustion efficiency of the furfuryl alcohol (Figure 6b) and attributable to the richer engine operation (Table 3) increasing the extent of fuel rich regions of the in-cylinder mixture necessary for soot formation and decreasing the availability of oxygen for subsequent oxidation of particulates. Figure $9 \mathrm{~b}$ shows the highest and lowest number of particles to have been emitted by the furfuryl alcohol and gamma valeracterone blends respectively. This is in agreement with the combustion efficiencies of the test fuel blends, of which the highest was observed in the case of the GVL blend (Figure 6b), suggesting in-cylinder conditions less suitable for conversion of unburnt fuel to particulates where combustion efficiencies were higher.

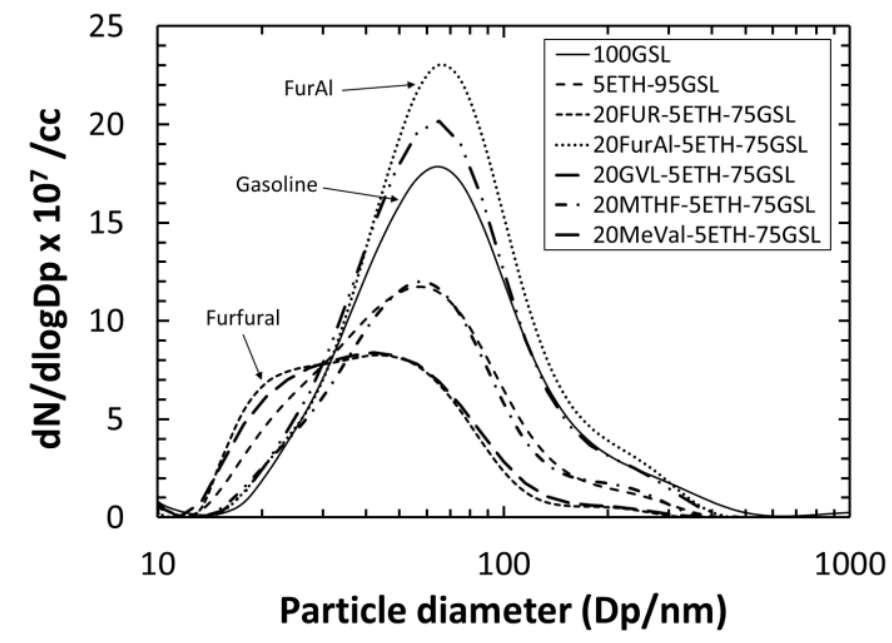

Figure 10: Particle number distribution for the various fuel blends, at a constant load of 9 bar IMEP and a fixed spark timing of 10 CAD BTDC.

Figure 10 shows the size distribution of the number of particulates in the engine exhaust from the various fuel blends, at a fixed spark timing of 10 CAD BTDC and a constant engine load of 9 bar IMEP. Concurrent with Figure 9b, the highest peak number of particles were emitted by the furfuryl alcohol blend, followed by the methyl valerate blend (MeVal) and reference gasoline. Also apparent in Figure 10 is that the largest mode particle diameter of approximately $80 \mathrm{~nm}$ was observed in the case of the furfuryl alcohol blend,

CITATION: Talibi, M., Hellier, P., and Ladommatos, N., "Investigating the Combustion and Emissions Characteristics of Biomass- Derived Platform Fuels as Gasoline Extenders in a Single Cylinder Spark-Ignition Engine," SAE Technical Paper 2017-01-2325, 2017, doi:10.4271/2017-01-2325. 
coinciding with the highest peak number of particles, while the smallest peak particle diameter was exhibited by the furfural blend at approximately $40 \mathrm{~nm}$. Furthermore, Figure 10 shows elevated emissions of nucleation mode particles of between $10 \mathrm{~nm}$ and $30 \mathrm{~nm}$ in diameter, concurrent with a lower number of larger accumulation mode particulates, in the case of the furfural and GVL blends, in agreement with the lowest total particulate mass emitted by both blends (Figure 9a).

\section{Conclusions}

The knock limits, combustion characteristics and exhaust emission levels of five fuels blends containing molecules which could potentially be derived from lignocellulosic biomass with varying levels of processing, were determined using a single cylinder, sparkignition research engine. The following conclusions can be drawn from the results:

1. The lowest resistance to knock was observed by the blends containing furfural and MTHF, while the highest knock resistance was exhibited by the furfuryl alcohol blend. The high knock limit of furfuryl alcohol relative to furfural was attributed to the presence of the $\mathrm{OH}$ functional group, which alters the fuel breakdown reactions, resulting in the formation of radicals which exhibit low reactivity, and hence greater resistance to auto-ignition.

2. The highest $\mathrm{NO}_{\mathbf{x}}$ emissions were obtained from the furfuryl alcohol blend, which was attributed to increased rates of thermal NOx production due to a higher peak heat release rates and thus likely in-cylinder temperatures relative to the other blends tested

3. The CO, particulate mass and total particle number exhaust emissions were also highest for the furfuryl alcohol and attributable to a richer air fuel mixture in the test of this blend, suggesting the air fuel stoichiometry to be a more important factor in determining these emissions than the properties of the tests fuel blends at these operating conditions. Elevated emissions of $\mathrm{CO}$ were also observed in the case of MTHF and potentially attributable to the high viscosity of this molecule, relative to the other fuels tested, which reduced rates of oxidation of the hydrocarbon fuel.

4. The size distribution of the exhaust particles varied for the different fuel blends, with those from furfural alcohol displaying the peak particle number of largest diameter and those emitted by furfural the lowest.

\section{References}

1. Gosling, S.N. and Arnell, N.W., "A global assessment of the impact of climate change on water scarcity," Clim. Change 134(3):371-385, 2016, doi:10.1007/s10584-013-0853-x.

2. Zecca, A. and Chiari, L., "Fossil-fuel constraints on global warming," Energy Policy 38(1):1-3, 2010, doi:10.1016/j.enpol.2009.06.068.

3. McGlade, C. and Ekins, P., "The geographical distribution of fossil fuels unused when limiting global warming to $2{ }^{\circ} \mathrm{C}$," Nature 517(7533):187-190, 2015, doi:10.1038/nature14016.

4. Turner, M.C., Jerrett, M., Pope, C.A., Krewski, D., Gapstur, S.M., Diver, W.R., Beckerman, B.S., Marshall, J.D., Su, J., Crouse, D.L., and Burnett, R.T., "Long-Term Ozone Exposure and Mortality in a Large Prospective Study," Am. J. Respir. Crit. Care Med. 193(10):1134-1142, 2016, doi:10.1164/rccm.201508-1633OC.

5. Wang, T., Jerrett, M., Sinsheimer, P., and Zhu, Y., "Estimating PM2.5-associated mortality increase in California due to the Volkswagen emission control defeat device," Atmos. Environ. 144:168-174, 2016, doi:10.1016/j.atmosenv.2016.08.074.

6. European Commission and European Parliament and Council, "Directive 2009/28/EC of the European Parliament and of the Council of 23 April 2009 on the promotion of the use of energy from renewable sources," Off. J. Eur. Union 16-62, 2009.

7. US EPA, "Renewable Fuel Standard (RFS),” http://www.epa.gov/otaq/fuels/renewablefuels/index.htm, 2005.

8. Yang, H., Zhou, Y., and Liu, J., "Land and water requirements of biofuel and implications for food supply and the environment in China," Energy Policy 37(5):1876-1885, 2009, doi:10.1016/j.enpol.2009.01.035.

9. The European Parliament and The Council of the European Union, DIRECTIVE (EU) 2015/1513 OF THE EUROPEAN PARLIAMENT AND OF THE COUNCIL, 2015.

10. Tuck, C.O., Pérez, E., Horváth, I.T., Sheldon, R.A., and Poliakoff, M., "Valorization of Biomass: Deriving More Value from Waste," Science (80-. ). 337(6095), 2012.

CITATION: Talibi, M., Hellier, P., and Ladommatos, N., "Investigating the Combustion and Emissions Characteristics of Biomass- Derived Platform Fuels as Gasoline Extenders in a Single Cylinder Spark-Ignition Engine," SAE Technical Paper 2017-01-2325, 2017, doi:10.4271/2017-01-2325. 
11. Dautzenberg, G., Gerhardt, M., and Kamm, B., "Bio based fuels and fuel additives from lignocellulose feedstock via the production of levulinic acid and furfural," Holzforschung 65(4):439-451, 2011, doi:10.1515/hf.2011.081.

12. Mariscal, R., Maireles-Torres, P., Ojeda, M., Sádaba, I., and López Granados, M., "Furfural: a renewable and versatile platform molecule for the synthesis of chemicals and fuels," Energy Environ. Sci. 9(4):1144-1189, 2016, doi:10.1039/C5EE02666K.

13. Yan, K. and Chen, A., "Selective hydrogenation of furfural and levulinic acid to biofuels on the ecofriendly Cu-Fe catalyst," Fuel 115:101-108, 2014.

14. Hoppe, F., Burke, U., Thewes, M., Heufer, A., Kremer, F., and Pischinger, S., "Tailor-Made Fuels from Biomass: Potentials of 2-butanone and 2-methylfuran in direct injection spark ignition engines," Fuel 167:106-117, 2016, doi:10.1016/j.fuel.2015.11.039.

15. Wang, C., Xu, H., Daniel, R., Ghafourian, A., Herreros, J.M., Shuai, S., and Ma, X., "Combustion characteristics and emissions of 2-methylfuran compared to 2,5-dimethylfuran, gasoline and ethanol in a DISI engine," Fuel 103(0):200-211, 2013.

16. Ma, X., Xu, H., Jiang, C., and Shuai, S., "Ultra-high speed imaging and OH-LIF study of DMF and MF combustion in a DISI optical engine,” Appl. Energy 122:247-260, 2014, doi:10.1016/j.apenergy.2014.01.071.

17. Wei, H., Feng, D., Shu, G., Pan, M., Guo, Y., Gao, D., and Li, W., "Experimental investigation on the combustion and emissions characteristics of 2-methylfuran gasoline blend fuel in spark-ignition engine," Appl. Energy 132:317-324, 2014, doi:10.1016/j.apenergy.2014.07.009.

18. Zhang, Q., Yao, M., Luo, J., Chen, H., and Zhang, X., "Diesel engine combustion and emissions of 2,5-dimethylfuran-diesel blends with 2-ethylhexyl nitrate addition," 2013, doi:10.1016/j.fuel.2013.04.009.

19. Zhang, Q., Chen, G., Zheng, Z., Liu, H., Xu, J., and Yao, M., "Combustion and emissions of 2,5-dimethylfuran addition on a diesel engine with low temperature combustion," Fuel 103(0):730-735, 2013.

20. Wang, J., Wang, X., Fan, X., Yang, K., and Zhang, Y., “An ignition delay time and kinetic study of 2-methyltetrahydrofuran at high temperatures," Fuel 186:758-769, 2016, doi:10.1016/j.fuel.2016.08.104.

21. Janssen, A.J., Kremer, F.W., Baron, J.H., Muether, M., Pischinger, S., and Klankermayer, J., "Tailor-Made Fuels from Biomass for Homogeneous Low-Temperature Diesel Combustion," Energy \& Fuels 25(10):4734-4744, 2011, doi:10.1021/ef2010139.

22. Sudholt, A., Cai, L., Heyne, J., Haas, F.M., Pitsch, H., and Dryer, F.L., "Ignition characteristics of a bio-derived class of saturated and unsaturated furans for engine applications," Proc. Combust. Inst. 35(3):2957-2965, 2015, doi:10.1016/j.proci.2014.06.147.

23. Boot, M.D., Tian, M., Hensen, E.J.M., and Mani Sarathy, S., "Impact of fuel molecular structure on auto-ignition behavior Design rules for future high performance gasolines," Prog. Energy Combust. Sci. 60:1-25, 2017, doi:10.1016/j.pecs.2016.12.001.

24. Lange, J.-P., Price, R., M.Ayoub, P., Louis, J., Petrus, L., Clarke, L., and Gosselink, H., "Valeric Biofuels: A Platform of Cellulosic Transportation Fuels," Angew. Chemie Int. Ed., 2010.

25. Bereczky, Á., Lukács, K., Farkas, M., and Dóbé, S., "Effect of $\gamma$-Valerolactone Blending on Engine Performance, Combustion Characteristics and Exhaust Emissions in a Diesel Engine," Nat. Resour. 5(5):177-191, 2014, doi:10.4236/nr.2014.55017.

26. Koivisto, E., Ladommatos, N., and Gold, M., "Compression Ignition and Exhaust Gas Emissions of Fuel Molecules Which Can Be Produced from Lignocellulosic Biomass: Levulinates, Valeric Esters, and Ketones,” Energy \& Fuels 29(9):5875-5884, 2015, doi:10.1021/acs.energyfuels.5b01314.

27. Zhen, X., Wang, Y., Xu, S., Zhu, Y., Tao, C., Xu, T., and Song, M., “The engine knock analysis - An overview,” Appl. Energy 92:628-636, 2012, doi:10.1016/j.apenergy.2011.11.079.

28. Wallner, T., "Correlation Between Speciated Hydrocarbon Emissions and Flame Ionization Detector Response for Gasoline/Alcohol Blends,” J. Eng. Gas Turbines Power 133(8):82801, 2011, doi:10.1115/1.4002893.

CITATION: Talibi, M., Hellier, P., and Ladommatos, N., "Investigating the Combustion and Emissions Characteristics of Biomass- Derived Platform Fuels as Gasoline Extenders in a Single Cylinder Spark-Ignition Engine," SAE Technical Paper 2017-01-2325, 2017, doi:10.4271/2017-01-2325. 
29. Nanda, S., Mohammad, J., Reddy, S.N., Kozinski, J.A., and Dalai, A.K., "Pathways of lignocellulosic biomass conversion to renewable fuels," Biomass Convers. Biorefinery 4(2):157-191, 2014, doi:10.1007/s13399-013-0097-z.

30. Murat Sen, S., Henao, C.A., Braden, D.J., Dumesic, J.A., and Maravelias, C.T., "Catalytic conversion of lignocellulosic biomass to fuels: Process development and technoeconomic evaluation,” Chem. Eng. Sci. 67(1):57-67, 2012, doi:10.1016/j.ces.2011.07.022.

31. Yan, K., Yang, Y., Chai, J., and Lu, Y., "Catalytic reactions of gamma-valerolactone: A platform to fuels and value-added chemicals,” Appl. Catal. B Environ. 179:292-304, 2015, doi:10.1016/j.apcatb.2015.04.030.

32. Yanowitz, J., Christensen, E., and Mccormick, R.L., "Utilization of Renewable Oxygenates as Gasoline Blending Components," National Renewable Energy Laboratory, 2011.

33. Sarathy, S.M., Oßwald, P., Hansen, N., and Kohse-Höinghaus, K., "Alcohol combustion chemistry,” Prog. Energy Combust. Sci. 44:40-102, 2014, doi:10.1016/j.pecs.2014.04.003.

34. El-Nahas, A.M., Navarro, M. V., Simmie, J.M., Bozzelli, J.W., Curran, H.J., Dooley, S., and Metcalfe, W., "Enthalpies of Formation, Bond Dissociation Energies and Reaction Paths for the Decomposition of Model Biofuels: Ethyl Propanoate and Methyl Butanoate †,” J. Phys. Chem. A 111(19):3727-3739, 2007, doi:10.1021/jp067413s.

35. Quelch, G.E., Gallo, M.M., Shen, M., Xie, Y., Schaefer, H.F., and Moncrieff, D., “Aspects of the Reaction Mechanism of Ethane Combustion. 2. Nature of the Intramolecular Hydrogen Transfer," J. Am. Chem. Soc. 116(11):4953-4962, 1994, doi:10.1021/ja00090a046.

36. Stark, M.S. and Waddington, D.J., "Oxidation of propene in the gas phase," Int. J. Chem. Kinet. 27(2):123-151, 1995, doi:10.1002/kin.550270205.

37. Heywood, J.B., "Internal Combustion Engine Fundementals," Internatio, McGraw-Hill Book Company, ISBN 007028637X, 1988.

38. Miller, J.A. and Bowman, C.T., "Mechanism and modeling of nitrogen chemistry in combustion,” Prog. Energy Combust. Sci. 15(4):287-338, 1989.

39. Zeldovich, Y.. B., Sadavnikov, P.Y., and Frank-Kamentskii, D.A., "Oxidation of Nitrogen in Combustion,” Acad. Sci. USSR, Moscow, 1947.

40. Bowman, C.T., "Kinetics of pollutant formation and destruction in combustion," Prog. Energy Combust. Sci. 1(1):33-45, 1975.

41. Tree, D.R. and Svensson, K.I., "Soot processes in compression ignition engines," Prog. Energy Combust. Sci. 33(3):272-309, 2007.

\section{Contact Information}

Corresponding author: Midhat Talibi, email: m.talibi@ucl.ac.uk Tel: +44 (0) 2076790012

\section{Acknowledgments}

The authors would like to acknowledge the UK Engineering and Physical Science Research Council (EPRSC grants EP/M009424/1 and EP/M007960/1) for their support of this project. The authors also wish to thank Mary Taylor and Chen Zekai for their assistance in LHV measurements.

CITATION: Talibi, M., Hellier, P., and Ladommatos, N., "Investigating the Combustion and Emissions Characteristics of Biomass- Derived Platform Fuels as Gasoline Extenders in a Single Cylinder Spark-Ignition Engine," SAE Technical Paper 2017-01-2325, 2017, doi:10.4271/2017-01-2325. 


\section{Nomenclature}

$\begin{array}{ll}\text { ATDC } & \text { after-top-dead-centre } \\ \text { BTDC } & \text { before-top-dead-centre } \\ \text { CAD } & \text { crank angle degree } \\ \text { CI } & \text { compression ignition } \\ \text { CO } & \text { carbon monoxide } \\ \text { CO2 } & \text { carbon dioxide } \\ \text { Dp } & \text { Particle diameter } \\ \text { EGR } & \text { exhaust gas recirculation } \\ \text { GVL } & \gamma \text {-valerolactone } \\ \text { IMEP } & \text { indicated mean effective pressures } \\ \text { MTHF } & \text { 2-methyltetrahydrofuran } \\ \text { NO } & \text { oxides of nitrogen } \\ \text { O2 } & \text { oxygen } \\ \text { PM } & \text { particulate matter } \\ \text { ppr } & \text { pulses per revolution } \\ \text { SCR } & \text { selective catalyst reduction } \\ \text { SOC } & \text { start of combustion } \\ \text { SOI } & \text { start of fuel injection } \\ \text { TDC } & \text { top-dead-centre } \\ \text { THC } & \text { total hydrocarbons } \\ \end{array}$

